\title{
IMPLEMENTASI KOOPERATIF TPS MENINGKATKAN AKTIVITAS DAN HASIL BELAJAR PASSING BOLA BASKET
}

\author{
I Wayan Eka Sugiantara1,* \\ 1 Universitas Pendidikan Ganesha
}

\begin{abstract}
Abstrak
Penelitian ini bertujuan untuk meningkatkan aktivitas dan hasil belajar teknik dasar passing (chest pass dan bounce pass) bola basket. melalui implementasi model pembelajaran kooperatif tipe TPS. Penelitian ini merupakan penelitian tindakan kelas, yaitu guru sebagai peneliti yang dilaksanakan dalam dua siklus, terdiri dari rencana tindakan, pelaksanaan tindakan, observasi dan evaluasi serta refleksi. Subjek penelitian ini adalah siswa kelas XI.MIPA.1 SMA Negeri 2 Singaraja, sejumlah 36 orang, yaitu 23 orang perempuan dan 13 orang laki-laki. Data dianalisis menggunnakan statistik deskriptif. Hasil analisis data aktivitas belajar secara klasikal teknik dasar passing bola basket pada siklus I adalah 7,2 (aktif), dan meningkat menjadi 8,5 (aktif) pada siklus. Sedangkan ketuntasan hasil belajar secara klasikal pada siklus I adalah 80,5\% (baik), dan meningkat menjadi 100\% (sangat baik) pada siklus II. Dapat disimpulkan bahwa aktivitas dan hasil belajar teknik dasar passing (chest pass dan bounce pass) bola basket meningkat melalui implementasi model pembelajaran kooperatif tipe TPS pada siswa kelas XI.MIPA.1 SMA Negeri 2 Singaraja tahun pelajaran 2017/2018. Maka disarankan kepada guru penjasorkes agar mengimplementasikan model pembelajaran kooperatif tipe TPS ini karena terbukti dapat meningkatkan aktivitas dan hasil belajar teknik dasar passing (chest pass dan bounce pass) bola basket.
\end{abstract}

\author{
Kata-kata Kunci: \\ TPS, aktivitas, hasil \\ belajar, bola basket.
}

\section{Pendahuluan}

Pembelajaran merupakan suatu proses yang melibatkan interaksi antara peserta didik dengan guru maupun peserta didik dengan peserta didik dimana dari interaksi tersebut peserta didik diharapkan mendapatkan pemahaman dan kemajuan hasil belajar tentang ajaran yang diperoleh dalam situasi pembelajaran. Dalam pelaksanaan pembelajaran tersebut selalu terkait dengan beberapa faktor, salah satunya adalah faktor internal peserta didik yang bersangkutan. Faktor internal peserta didik adalah faktor yang timbul dari dalam peserta didik, seperti peserta didik kurang tertarik terhadap materi pembelajaran yang diberikan.

Pembelajaran Pendidikan Jasmani Olahraga dan Kesehatan (PJOK) pada khususnya masih mengalami permasalahan karena model pembelajaran yang digunakan masih kurang maksimal penggunaan model pembelajaran sehingga peserta didik cepat akan merasa bosan dalam mengikuti proses pembelajaran, ini dapat dilihat melalui observasi yang dilakukan peneliti dan masalah yang ditemukan dari hasil observasi tersebut yaitu proses pembelajaran masih berpusat pada guru, guru belum terlalu memaksimalkan fungsi kelompok dalam pembelajaran, selama ini pembentukan kelompok hanya sebatas mempermudah melakukan presensi, dan peserta didik masih terlihat canggung untuk menyampaikan kesulitan-kesulitan dalam melakukan tugas gerak. Selain itu beberapa peserta didik menganggap PJOK adalah mata pelajaran yang menakutkan karena memerlukan kesiapan fisik untuk melakukan tugas gerak. Berdasarkan hasil pengamatan terlihat terdapat peserta didik yang mengalami kesulitan tugas gerak namun tidak berani bertanya, selain itu terdapat juga peserta didik yang tidak berani mencoba dengan alasan takut cedera. Dan beberapa peserta didik yang sudah menguasai tugas gerak dengan baik mendominasi aktivitas pembelajaran tanpa berbagi dengan temannya yang mengalami kesulitan. 
Berdasarkan hasil observasi awal dan wawancara dengan guru PJOK yang peneliti lakukan pada tanggal 25 Juli 2017 di kelas XI.MIPA.1 SMA Negeri 2 Singaraja. Siswa kelas XI.MIPA.1 SMA Negeri 2 Singaraja yang berjumlah 36 orang Aktivitas belajar yang mencakup kegiatan visual, kegiatan lisan, kegiatan audio, kegiatan metrik, kegiatan mental, dan kegiatan emosional, penulis memperoleh gambaran tentang aktivitas belajar siswa yang masih belum aktif. Persentase aktivitas belajar teknik passing (chest pass dan bounce pass) bola basket siswa yang berada pada kategori sangat aktif 0 orang (0\%), aktif sebanyak 13 orang (36\%), cukup aktif sebanyak 15 orang (41\%), dan kurang aktif sebanyak 8 orang (23\%). Dilihat dari persentase aktivitas belajar teknik passing (chest pass dan bounce pass) bola basket, siswa secara klasikal adalah 6,1 berada pada kriteria $5 X<7$ termasuk kategori belum aktif. Siswa yang aktif yaitu $36 \%$ sebanyak 13 orang dan siswa yang belum aktif yaitu $64 \%$ sebanyak 23 orang. Aktivitas belajar siswa dikatakan berhasil minimal berada pada kategori aktif dengan kriteria $7 \quad X<9$.

Hasil belajar yang menakup tiga aspek yaitu aspek pengetahuan, aspek sikap dan aspek keterampilan masih termasuk belum tuntas. Dilihat dari persentase hasil belajar teknik passing (chest pass dan bounce pass) bola basket, siswa yang berada pada kategori sangat baik sebanyak (0\%), baik sebanyak 3 orang $(8,3 \%)$, cukup baik sebanyak 10 orang $(27,7 \%)$, kurang baik sebanyak 23 orang $(64 \%)$, dan sangat kurang baik (0\%). Persentase hasil belajar teknik passing (chest pass dan bounce pass) bola basket, siswa secara klasikal adalah 67 berada pada rentang skor $<70$ termasuk kategori kurang baik. Siswa yang tuntas yaitu 36\% sebanyak 13 orang dan siswa yang belum tuntas yaitu 64\% sebanyak 23 orang. Dengan menganalisa hasil belajar siswa, berpedoman pada konversi nilai mata PJOK khususnya materi teknik passing (chest pass dan bounce pass) bola basket SMA Negeri 2 Singaraja, kriteria ketuntasan hasil belajar siswa minimal rentang skornya adalah 70\%-79\% tuntas tetapi masih kategori predikat cukup baik

Berdasarkan hasil refleksi awal yang dilakukan oleh peneliti di SMA Negeri 2 Singaraja, permasalahan terletak pada aktivitas belajar. Aktivitas belajar siswa belum aktif terlihat dari: 1) kegiatan visual, 2) kegiatan lisan, 3) kegiatan audio, 4) kegiatan metrik, 5) kegiatan mental, dan 6) kegiatan emosional. Sedangkan hasil belajar siswa belum tuntas itu terlihat pada: (1) aspek pengetahuan yaitu masih ada beberapa pertanyaan yang belum dapat dijawab oleh siswa pada materi pembelajaran; (2) aspek sikap yaitu masih ada beberapa siswa yang belum bekerjasama denag tim/teman, menaati aturan tugas gerak dan menghargai saran/pendapat teman, dan (3) aspek keterampilan: a) sikap awal passing atas, siswa masih berada pada posisi tegak dan jari belum membentuk seperti mangkok, b) pada saat pelaksanaan, tangan belum belum lurus sehingga alur bola belum menuju sasaran, c) pada saat sikap akhir, peserta didik belum memindahkan berat badan kedepan dengan melangkahkan kaki belakang kedepan.

Berdasarkan hasil refleksi awal oleh peserta didik melalui pemberian kuesioner, permasalahan yang dihadapi peserta didik dalam proses pembelajaran PJOK yaitu: (a) sarana dan prasarana yang kurang memadai (b) banyak siswa yang kurang berkosentrasi dan bercanda pada saat melakukan gerakan, (c) tidak ada kerja sama dengan teman dalam melakukan aktivitas gerak, (d) proses pembelajaran kurang menarik dan selalu menoton sehingga cepat bosan dan jenuh, (e) gerakan yang cukup sukar untuk dilakukan.

Bertolak dari uraian di atas maka peneliti mencoba memberikan alternatif pemecahan masalah untuk pembelajaran selanjutnya pada materi passing bola basket yaitu dengan menggunakan model pembelajaran kooperatif tipe TPS. Karena model pembelajaran kooperatif tipe TPS yang menuntut para peserta didik untuk memiliki kemampuan yang baik dalam berkomunikasi maupun dalam keterampilan proses kelompok. Penerapan model pembelajaran tipe TPS akan membuat peserta didik, (1) lebih aktif untuk menemukan konsep PJOK, mengembangkan sendiri fakta, teori, dan prinsip yang ditemukan, serta memecahkan masalah yang ditemukan berdasarkan konsep yang ada, sehingga peserta didik terhindar dari belajar menghafal, (2) lebih kreatif dan komperhensif untuk menyampaikan gagasan, bertanya dan menanggapi setiap permasalahan yang disampaikan, (3) memudahkan peserta didik melakukan penyesuaian sosial dan secara tidak langsung belajar dasar-dasar berorganisasi, (4) menghilangkan sifat mementingkan diri sendiri atau egois dan egosentris, (5) membangun persahabatan yang dapat berlanjut hingga masa dewasa, (6) merubah pandangan peserta didik terhadap guru, bahwa guru sebagai fasilitator bukan sebagai penunjang keberhasilan akademik. Dari penerapan model pembelajaran kooperatif tipe TPS tersebut, diharapkan nantinya mampu memotivasi peserta didik untuk belajar dengan baik dan merubah pandangan mereka terhadap mata pelajaran PJOK dari pelajaran yang membosankan menjadi pelajaran yang menarik, tetapi juga berdampak pada peningkatan kompetensi dasar peserta didik.

Pemilihan tentang model pembelajaran TPS ini juga dikuatkan oleh hasil penelitian dari penelitipeneliti sebelumnya, diantaranya; 1) I komang Wiwik Sandita menemukan bahwa aktivitas dan hasil belajar teknik dasar passing bola sepak meningkat melalui penerapan model pembelajaran kooperatif tipe TPS pada siswa kelas X.1 SMA Negeri 1 Belah Batuh tahun pelajaran 2011/2012; 2) I Putu Junta Astu menemukan bahwa aktivitas dan hasi belajar lompat jauh meningkat melalui penerapan model 
pembelajaran kooperatif tipe TPS pada siswa kelas VIID SMP Negeri 2 Abang tahun pelajaran 2011/2012; 3) Igusti Ngurah Manik Mahardika menemukan bahwa aktivitas dan hasi belajar teknik dasar lari jarak pendek (sprint) meningkat melalui penerapan model pembelajaran kooperatif tipe TPS pada siswa kelas X keuangan SMK PGRI 1 Singaraja tahun pelajaran 2011/2012; 4) Kadek Dian Vanagosi menemukan bahwa aktivitas dan hasi belajar teknik dasar menggiring bola basket meningkat melalui penerapan model pembelajaran kooperatif tipe TPS pada siswa kelas VIIA SMP Negeri 1 Seririt tahun pelajaran 2011/2012; 5) Luh Made Satria Yuliantari menemukan bahwa aktivitas dan hasil belajar roll dalam pembelajaran senam lantai meningkat melalui penerapan model pembelajaran kooperatif tipe TPS pada siswa kelas XI SMA Negeri 1 Seririt tahun pelajaran 2011/2012.

Berdasarkan uraian di atas peneliti merasa terdorong untuk melakukan penelitian yang berjudul "Implementasi Model Pembelajaran Kooperatif Tipe TPS Untuk Meningkatkan Aktvitas dan Hasil Belajar Passing Bola Basket pada Peserta Didik Kelas XI.MIPA.1 SMA Negeri 2 Singaraja Tahun Pelajaran $2017 / 2018$.

\section{Metode}

Jenis penelitian yang digunakan adalah penelitian tindakan kelas (PTK). Penelitian tindakan kelas adalah suatu bentuk penelitian yang bersifat reflektif dengan tindakan-tindakan tertentu agar dapat memperbaiki atau meningkatkan praktik-praktik pembelajaran di kelas secara profesional (Kanca, 2010: 108).

Menurut Oja SN (Kanca, 2010: 115) membedakan adanya empat bentuk penelitian tindakan kelas yaitu: (1) Guru sebagai peneliti, (2) Penelitian tindakan kolaboratif, (3) Simultan-terintegrasi, dan (4) Administrasi sosial eksperimental. Dalam penelitian ini yang digunakan, yaitu: guru sebagi peneliti mempunyai ciri penting, yaitu: guru itu sangat berperan di dlam PTK tersebut dalam bentuk ini tujuan PTK itu sendiri ialah untuk meningkatkan praktek-praktek pembelajaran di kelas dimana guru terlibat secara penuh didalam proses perencanaan, aksi (tindakan) dan refleksi.

Dalam penelitian ini dimana guru akan menggunakan penelitian yaitu guru sebagai peneliti, penelitian ini guru berperan dalam proses pembelajaran PTK di dalam meningkatkan praktek-praktek pembelajaran di kelas serta guru terlibat secara penuh di dalam proses perencanaaan, aksi (tindakan) dan dalam refleksi (Kanca, 2010:115).

Bentuk penelitian tindakan kelas akan digunakan dalam penelitian ini guru sebagai peneliti, yaitu guru dalam hal ini penelitian berperan sangat penting dalam proses PTK. Dalam bentuk ini tujuan utama PTK adalah untuk meningkatkan praktek-praktek pembelajaran di kelas dimana guru terlibat secara penuh dalam proses perencanaan, aksi (tindakan), dan refleksi yang dimana penelitian ini bertujuan untuk meningkatkan aktivitas dan hasil belajar siswa.

\section{Hasil dan Pembahasan}

Penelitian ini dilaksanakan dalam dua siklus, dimana setiap siklus terdiri dari dua kali pertemuan, yaitu yang dilaksanakan setiap hari selasa mulai pukul $05.30 \mathrm{~s} / \mathrm{d} 07.45$ wita. Penelitian siklus I dilaksanakan pada tanggal 5 September 2017 untuk pengambilan data aktivitas belajar siswa dan tanggal 12 September 2017 untuk pengambilan data aktivitas dan hasil belajar siswa. Sedangkan penelitian siklus II dilaksanakan pada tanggal 19 September 2017 untuk pengambilan data aktivitas belajar dan tanggal 26 September 2017 untuk pengambilan data aktivitas serta hasil belajar siswa. Tempat penelitian di Lapangan Upacara/Lapangan Basket SMA Negeri 2 Singaraja pada siswa kelas XI.MIPA.1 SMA Negeri 2 Singaraja tahun pelajaran 2017/2018 yang berjumlah 36 orang siswa yang terdiri dari 23 orang siswa putra dan 13 orang siswa putri.

Data aktivitas belajar teknik dasar passing (chest pass dan bounce pass) bola basket siklus I dalam proses pembelajaran teknik dasar passing (chest pass dan bounce pass) bola basket pada siswa kelas kelas XI.MIPA.1 SMA Negeri 2 Singaraja, siswa dengan kategori sangat aktif sebanyak 0 siswa dengan persentase $0 \%$, siswa dengan kategori aktif sebanyak 18 siswa dengan persentase 50\%, siswa dengan kategori cukup aktif sebanyak 18 siswa dengan persentase 50\%, siswa dengan kategori kurang aktif sebanyak 0 siswa dengan persentase $0 \%$ dan siswa dengan kategori sangat kurang aktif sebanyak 0 siswa dengan persentase $0 \%$. 
Tabel 1. Data Aktivitas Belajar passing bola basket siklus I

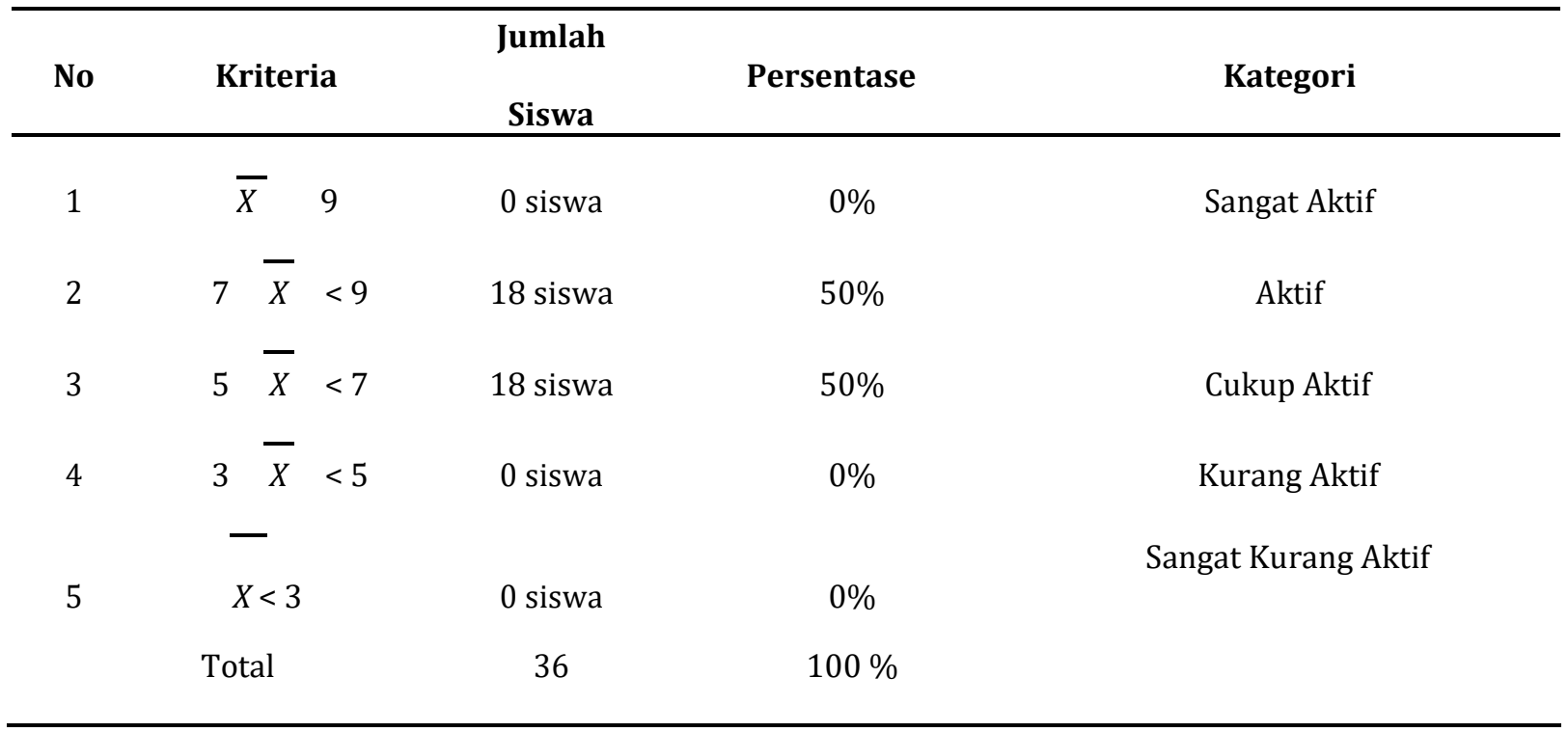

Penelitian hasil belajar siswa teknik dasar passing (chest pass dan bounce pass) bola basket pada siklus I diperoleh data hasil belajar dimana siswa yang tuntas sebanyak 29 siswa dengan persentase $80^{\prime} 5 \%$ dan yang tidak tuntas sebanyak 7 siswa dengan persentase 19'5\% dengan rincian kategori hasil belajar sebagai berikut: siswa dengan kategori sangat baik sebanyak 0 orang dengan persentase $0 \%$, siswa dengan kategori baik sebanyak 6 orang dengan persentase 17\%, siswa dengan kategori cukup baik sebanyak 23 orang dengan persentase 63,5\%, siswa dengan kategori kurang baik sebanyak 7 orang dengan persentase $19^{\prime} 5 \%$ dan siswa dengan kategori sangat kurang sebanyak 0 orang dengan persentase $0 \%$.

Tabel 2. Data Hasil Belajar passing bola basket siklus I

Sikap, Pengetahuan dan Keterampilan

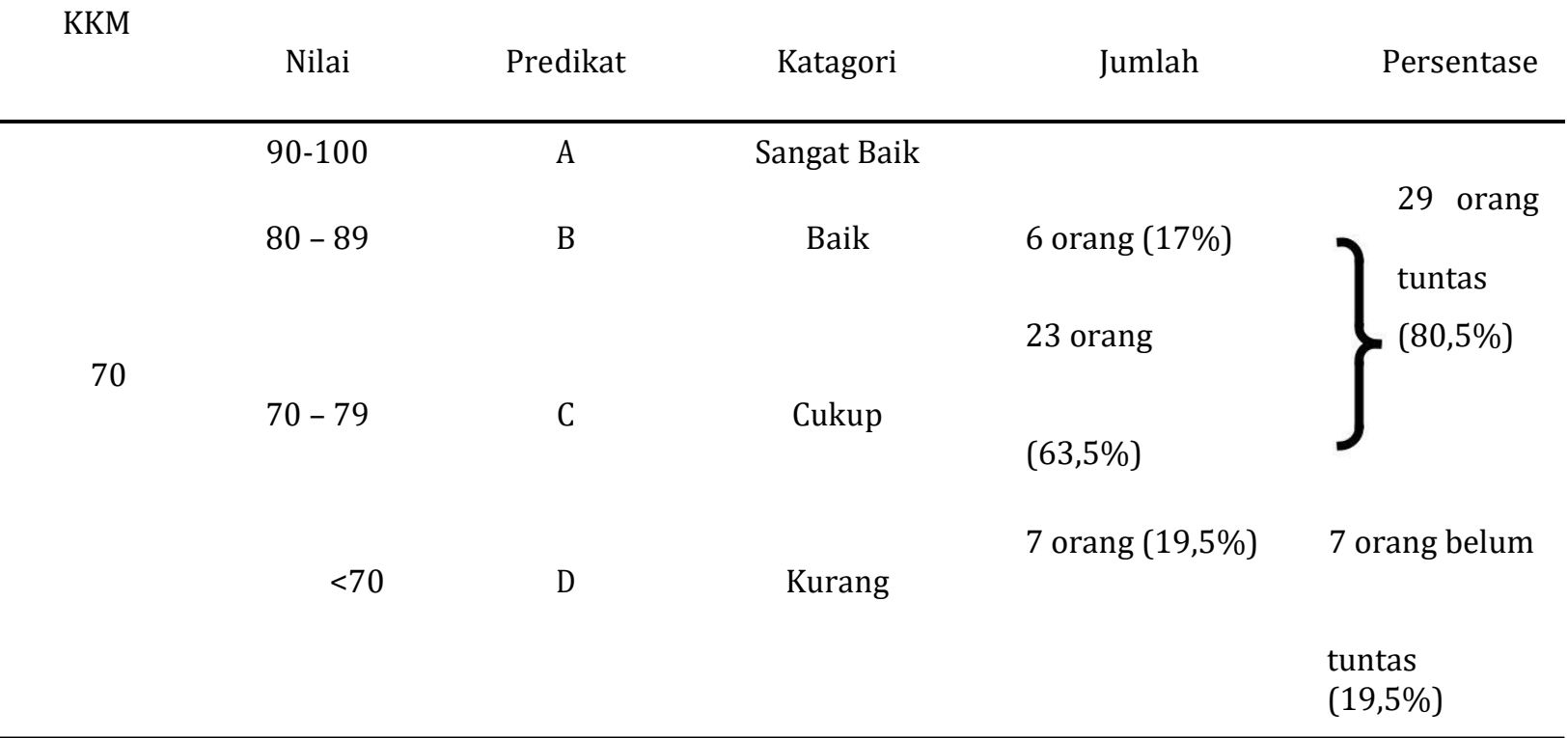

Data aktivitas belajar siswa pada siklus II diperoleh dengan menggunakan metode observasi terhadap kemunculan indikator aktivitas belajar sesuai dengan yang tertera pada lembar observasi aktivitas belajar siswa pada siklus II materi teknik dasar passing (chest pass dan bounce pass) bola basket siswa dengan kategori kategori sangat aktif sebanyak 15 orang dengan persentase 41'6\%, siswa dengan kategori aktif sebanyak 21 orang dengan persentase 58,4\%, siswa dengan kategori cukup aktif sebanyak 0 
orang dengan persentase $0 \%$, siswa dengan kategori kurang aktif sebanyak 0 orang dengan persentase $0 \%$ dan siswa dengan kategori sangat kurang aktif sebanyak 0 orang dengan persentase $0 \%$.

Tabel 3. Kategori penggolongan aktivitas belajar passing bola basket pada siklus II

\begin{tabular}{|c|c|c|c|c|c|}
\hline No & Kriteri: & & Kategori & Jumlah Siswa & Dalam \% \\
\hline 1 & $\bar{X}$ & 9 & Sangat Aktif & 15 siswa & $41^{\prime} 6 \%$ \\
\hline 2 & $\bar{X}$ & $<9$ & Aktif & 21 siswa & $58,4 \%$ \\
\hline 3 & $\bar{X}$ & $<7$ & Cukup Aktif & 0 siswa & $0 \%$ \\
\hline 4 & $\bar{X}$ & $<5$ & Kurang Aktif & 0 siswa & $0 \%$ \\
\hline 5 & $\bar{X}<3$ & & Sangat Kurang Aktif & 0 siswa & $0 \%$ \\
\hline \multicolumn{4}{|c|}{ Jumlah } & 36 siswa & $100 \%$ \\
\hline
\end{tabular}

Penelitian hasil belajar siswa pada siklus II dengan materi teknik dasar passing (chest pass dan bounce pass) bola basket diperoleh data hasil belajar, dimana siswa yang kategori sangat aktif sebanyak 1 orang dengan persentase 3,33\%, siswa dengan kategori aktif sebanyak 29 orang dengan persentase $96,64 \%$, siswa dengan kategori cukup aktif sebanyak 0 orang dengan persentase $0 \%$, siswa dengan kategori kurang aktif sebanyak 0 orang dengan persentase $0 \%$ dan siswa dengan kategori sangat kurang aktif sebanyak 0 orang dengan persentase $0 \%$.

Tabel 4. Kategori penggolongan ketuntasan hasil belajar passing bola basket pada siklus II

\begin{tabular}{|c|c|c|c|c|c|}
\hline \multirow{2}{*}{ KKM } & \multicolumn{4}{|c|}{ Sikap, Pengetahuan dan Keterampilan } & \multirow[b]{2}{*}{ Persentase } \\
\hline & Nilai & Predikat & Katagori & Jumlah & \\
\hline \multirow{4}{*}{70} & $90-100$ & A & Sangat Baik & 7 orang $(19,5 \%)$ & \\
\hline & $80-89$ & B & Baik & $\begin{array}{l}29 \text { orang } \\
(80,5 \%)\end{array}$ & $\begin{array}{l}36 \quad \text { orang } \\
\text { tuntas } \\
(100 \%\end{array}$ \\
\hline & $70-79$ & $\mathrm{C}$ & Cukup & & \\
\hline & $<70$ & D & Kurang & 36 orang & \\
\hline
\end{tabular}

Hasil analisis data aktivitas belajar siswa teknik dasar passing (chest pass dan bounce pass) bola basket diperoleh data hasil belajar, dimana siswa yang tuntas sebanyak 36 orangsiswa dengan persentase $100 \%$ dan siswa yang tidak tuntas tidak ada. Adapun rincian kategori sebagai berikut: Dapat disampaikan bahwa pada pada siklus I siswa yang aktif sebanyak 18 orang (50\%), Karena pada siklus I aktivitas siswa masih perlu ditingkatkan, sehingga pada siklus II kembali diberikan tindakan. Setelah diberikan tindakan pada siklus II, aktivitas siswa meningkat sebanyak 18 orang (50\%) dari siklus I dan pada siklus II semua siswa sudah berada dalam kategori aktif yaitu 36 orang $(100 \%)$, dan dari siklus 1 ke siklus II terjadi peningkatan sebesar 18 orang (50\%). 
Tabel 5. Ringkasan Data Peningkatan Aktivitas Belajar Siswa

\begin{tabular}{|c|c|c|c|c|}
\hline No & Tahapan & $\begin{array}{c}\text { Aktivitas Belajar } \\
\text { Klasikal }\end{array}$ & Keaktifan Siswa & $\begin{array}{c}\text { Peningkatan Siklus I } \\
\text { ke Siklus II }\end{array}$ \\
\hline 1 & Siklus I & 7,2 & $\begin{array}{c}18 \text { siswa }(50 \%) \\
\text { Aktif }\end{array}$ & \\
\hline 2 & Siklus II & 8,5 & $\begin{array}{c}36 \text { siswa }(100 \%) \\
\text { Aktif }\end{array}$ & 18 siswa $(50 \%)$ \\
\hline
\end{tabular}

Hasil belajar siswa teknik dasar passing (chest pass dan bounce pass) bola basket pada siswa kelas XI.MIPA.1 SMA Negeri 2 Singaraja dapat disampaikan persentase hasil belajar pada siklus I sebesar 29\% (80,5 siswa). Karena pada siklus I masih ada siswa yang belum tuntas maka diberikan tindakan pada siklus II. Setelah diberikan tindakan pada siklus II persentase hasil belajar siswa menjadi $100 \%$ (36 siswa) meningkat sebesar 19,5\% (7 siswa) dari siklus I. Dari hasil analisis data tersebut dapat dilihat peningkatan persentase hasil belajar yang terjadi dari siklus 1 ke siklus II sebesar 19,5\% (7 siswa).

Tabel 6. Ringkasan Data Peningkatan Hasil Belajar Siswa

$\left.\begin{array}{ccccc}\hline \text { No } & \text { Tahapan } & \begin{array}{c}\text { Persentase Hasil } \\ \text { Belajar }\end{array} & \begin{array}{c}\text { Ketuntasan } \\ \text { Siswa }\end{array} & \begin{array}{c}\text { Peningkatan Siklus I } \\ \text { ke Siklus II }\end{array} \\ \hline 1 & \text { Siklus I } & \begin{array}{c}29 \text { siswa }(80,5 \%) \\ \text { tuntas }\end{array} & \text { Tuntas } & \\ & & 36 \text { siswa (100\%) } & \\ & \text { Siklus II } & \text { tuntas } & \text { Tuntas }\end{array}\right\} \begin{gathered}7 \text { siswa }(19,5 \%) \\ -\end{gathered}$

Berdasarkan hasil penelitian yang telah dilakukan selama dua siklus, menunjukkan terjadi peningkatan aktivitas dan hasil belajar siswa dengan penerapan model pembelajaran kooperatif tipe TPS. Adapun data yang diperoleh berdasarkan analisis data pada siklus I yaitu persentase aktivitas belajar siswa dalam proses pembelajaran sebesar 7,2. Dari kriteria $7 X<9$ pada siklus I tergolong aktif. Adapun rinciannya yaitu siswa dengan kategori sangat aktif sebanyak 0 siswa dengan persentase $0 \%$, siswa dengan kategori aktif sebanyak 18 siswa dengan persentase 50\%, siswa dengan kategori cukup aktif sebanyak 18 siswa dengan persentase $50 \%$, siswa dengan kategori kurang aktif sebanyak 0 siswa dengan persentase $0 \%$ dan siswa dengan kategori sangat kurang aktif sebanyak 0 siswa dengan persentase $0 \%$.

Permasalahan-permasalahan aktivitas belajar yang dihadapi pada siklus I yaitu: Lisan; pada aspek; (b) Siswa masih belum berani mengemukakan pendapat dan memberikan saran dalam diskusi. Audio; pada aspek; (b) siswa kurang mendengarkan diskusi dalam kelompok tentang materi teknik dasar passing (chest pass dan bounce pass) bola basket yang dipelajarinya. Metrik; pada aspek; (b) Siswa belum berani melakukan percobaan gerakan-gerakan baru yang dapat membantu menyempurnakan teknik dasar passing (chest pass dan bounce pass) bola basket. Mental; pada aspek; (b) siswa belum bisa memecahkan masalah yang dihadapi dalam proses pembelajaran teknik dasar passing (chest pass dan bounce pass) bola basket. Emosional; pada aspek; (b) siswa kurang berani dalam menghadapi dan memecahkan masalah dalam pembelajaran teknik dasar passing (chest pass dan bounce pass) bola basket.

Tindakan-tindakan yang dilakukan untuk mengatasi permasalahan pada saat pembelajaran adalah sebagai berikut. Lisan; pada aspek; (b) peneliti memotivasi siswa untuk menyimak penjelasan tentang materi yang disajikan. Audio; pada aspek; (b) peneliti memotivasi siswa agar saling berdiskusi dan saling mendengarkan materi teknik dasar passing (chest pass dan bounce pass) bola basket yang disampaikan oleh temannya. Metrik; pada aspek; (b) memberikan petunjuk agar siswa dapat melakukan gerakan dengan baik. Mental; pada aspek; 
(b) membantu siswa dalam memecahkan masalah yang dihadapi. Emosional; pada aspek; (b) membantu dan mendampingi siswa agar berani dalam menghadapi dan memecahkan masalah dalam pembelajaran teknik dasar passing (chest pass dan bounce pass) bola basket.

(c) Sedangkan persentase hasil belajar siswa teknik dasar passing (chest pass dan bounce pass) bola basket pada siklus I dengan kategori sangat baik sebanyak 0 orang dengan persentase $0 \%$, siswa dengan kategori baik sebanyak 6 orang dengan persentase 17\%, siswa dengan kategori cukup baik sebanyak 23 orang dengan persentase $63,5 \%$, siswa dengan kategori kurang baik sebanyak 7 orang dengan persentase $19,5 \%$ dan siswa dengan kategori sangat kurang sebanyak 0 orang dengan persentase $0 \%$.

Adapun permasalahan-permasalahan hasil belajar yang dihadapi siswa yaitu pada aspek kognitif siswa kurang mampu memahami materi yang diberikan pada saat pembelajaran sehingga pada saat pemberian tes pengetahuan siswa masih kurang mampu mengembangkan pengetahuannya. Pada penilaian sikap beberapa siswa kurang menghargai rekan sekelas dalam kelompoknya, selain itu juga siswa kurang bersemangat mengikuti pembelajaran. Sedangkan pada aspek ketrampilan dalam melakukan gerakan teknik dasar passing chest pass dan bounce pass) bola basket ada beberapa komponen yang tidak dilakukan secara baik. dalam sikap awal komponen (b) badan siswa terkadang tidak condong ke depan dan kedua tangan memegang bola belum di depan dada, komponen (c) jari-jari tangan belum dibuka lebar, untuk sikap pelaksanaan komponen (a) saat melempar bola, siswa belum melangkahkan salah satu kaki ke depan, (c) pada saat melempar bola kedua tangan belum dibantu dengan kekuatan menggerakkan badan, (e) Arah lemparan belum depan dada dan pada sikap akhir, komponen (c) pandangan siswa tidak mengikuti arah bola. sikap awal pada komponen (b) badan siswa belum condong ke depan, sikap pelaksanaan pada komponen (b) masih sulit dilakukan oleh siswa (d) kurang mengkoordinasikan gerakan dan pada sikap akhir komponen (c) pandangan siswa belum ke arah sasaran. Berdasarkan permasalahan yang dihadapi pada siklus I dan untuk memperbaiki aktivitas dan hasil belajar siswa sesuai dengan kurikulum, maka pada siklus II peneliti memberikan tindakan-tindakan yang dilakukan untuk memecahkan masalah tersebut dengan memberi penjelasan kepada siswa mengenai teknik dasar passing (chest pass dan bounce pass) dimana terdapat 3 hal yang harus diperhatikan yaitu sikap awal, sikap pelaksanaan dan sikap akhir. 3 hal tersebut saling berkaitan sehingga akan menghasilkan gerakan yang baik pada passing (chest pass dan bounce pass) bola basket. Siswa lebih banyak melakukan percobaan-percobaan passing (chest pass dan bounce pass) bola basket dan berdiskusi mengenai gerakan yang dilakukan di kelompoknya masing-masing. Peneliti juga membantu kesulitan siswa dalam melakukan gerakan mana yang sulit dilakukan sehingga diharapkan siswa bisa melakukan gerakan passing (chest pass dan bounce pass) bola basket dengan baik dan benar.

Pembelajaran pada siklus II berlangsung sangat kondusif, siswa sudah mampu beradaptasi dengan model pembelajaran kooperatif tipe TPS. Hal ini terlihat dari aktivitas belajar siswa saat peneliti memperagakan gerakan, siswa tidak lagi hanya menonton tetapi ikut aktif dalam memberikan komentar terhadap penjelasan peneliti di setiap tahap gerakan yang diperagakan oleh peneliti maupun teman kelompoknya.

Dilihat dari data aktivitas belajar siswa teknik dasar passing (chest pass dan bounce pass) bola basket pada siklus II sebesar 8,5. Dari kriteria $7 X<9$, maka aktivitas belajar siswa pada siklus II tergolong aktif. Adapun rincian kategori aktivitas belajar yaitu siswa dengan kategori sangat aktif sebanyak 15 orang $(41,6 \%)$, siswa dengan kategori aktif sebanyak 21 orang $(58,4 \%)$, siswa dengan kategori cukup aktif tidak ada, siswa dengan kategori kurang aktif tidak ada dan siswa dengan kategori sangat kurang tidak ada. Dari data tersebut terjadi peningkatan dari siklus I ke siklus II sebesar 50\%.

Sedangkan persentase hasil belajar siswa teknik dasar passing (chest pass dan bounce pass) bola basket pada siklus II. Adapun rinciannya yaitu siswa dengan kategori sangat baik sebanyak 7 orang $(19,5 \%)$, siswa dengan kategori baik sebanyak 29 orang $(80,5 \%)$, siswa dengan kategori cukup baik tidak ada, siswa dengan kategori kurang baik tidak ada dan siswa dengan kategori sangat kurang tidak ada.

Dengan memperhatikan data hasil belajar pada siklus II dalam hal ini hasil belajar teknik dasar passing (chest pass dan bounce pass) bola basket semua siswa tuntas. Dari data tersebut terjadi peningkatan dari siklus I ke siklus II sebesar 19,5\%. Peningkatan ini tidak terlepas dari penerapan model pembelajaran kooperatif tipe TPS secara optimal dengan perbaikan-perbaikan pembelajaran sesuai dengan kekurangan-kekurangan yang terjadi pada setiap siklus sebelumnya.

Keberhasilan dalam penelitian sesuai dengan teori-teori yang mendukung dalam proses pembelajaran. Hamalik (2008: 171-172) menyatakan bahwa "pembelajaran yang efektif adalah pembelajaran yang menyediakan kesempatan belajar sendiri dan beraktivitas sendiri kepada siswa". Siswa belajar dan beraktivitas sendiri untuk memperoleh pengalaman, pengetahuan, pemahaman, dan tingkah laku lainnya serta mengembangkan keterampilan yang bermakna. Sehingga dapat disimpulkan bahwa kegiatan atau aktivitas belajar siswa merupakan dasar untuk mencapai hasil belajar yang optimal. 
Selain itu hasil penelitian ini juga didukung dan dikuatkan oleh peneliti-peneliti sebelumnya diantaranya: (1) Adi (2013:8) menemukan bahwa aktivitas dan hasil belajar teknik passing bola basket (chest pass dan bounce pass) meningkat melalui implementasi model pembelajaran kooperatif tipe TPS pada siswa kelas VIII A SMP Negeri 1 Seririt tahun pelajaran 2012/2013, (2) Putrawan (2013) menemukan bahwa aktivitas dan hasil belajar teknik dasar passing (bawah dan atas) bola voli meningkat melalui penerapan model pembelajaran kooperatif tipe TPS pada siswa kelas VIII 1 SMP Negeri 4 Kuta Selatan tahun pelajaran 2012/2013, (3) Angga (2013:9) menemukan motivasi dan hasil belajar teknik dasar passing bola voli meningkat melalui implementasi model pembelajaran kooperatif tipe Think Pair Share (TPS) pada siswa kelas X 4 SMA Negeri 2 Semarapura tahun pelajaran 2012/2013, (4) Ardita (2013:10) menemukan bahwa aktivitas dan hasil belajar passing (bawah dan atas) bola voli meningkat melalui implementasi model pembelajaran kooperatif tipe TPS pada siswa kelas VIII A SMP Negeri 2 Blahbatuh tahun pelajaran 2012/2013, (5) Supardika (2013:8) menemukan bahwa aktivitas dan hasil belajar roll (roll depan dan roll belakang) senam lantai meningkat melalui penerapan model pembelajaran kooperatif tipe TPS pada siswa kelas VII.A SMP Negeri 4 Negara tahun pelajaran 2012/2013.

Penelitian-penelitian tersebut membuktikan bahwa dengan penerapan model pembelajaran kooperatif tipe TPS dapat meningkatkan aktivitas dan hasil belajar teknik dasar passing (chest pass dan bounce pass) bola basket serta dapat meningkatkan proses pembelajaran dalam berbagai bidang pembelajaran dan dalam berbagai jenjang pendidikan yang ada.

\section{Simpulan}

Berdasarkan teori-teori pendukung hasil penelitian yang dipaparkan di atas dapat disimpulkan bahwa aktivitas dan hasil belajar teknik dasar passing (chest pass dan bounce pass) bola basket meningkat melalui penerapan model pembelajaran kooperatif tipe TPS pada siswa kelas XI.MIPA.1 SMA Negeri 2 Singaraja tahun pelajaran 2017/2018.

Untuk itu disarankan kepada guru penjasorkes untuk berupaya menerapkan pembelajaran tipe TPS dalam proses pembelajaran sebagai salah satu alternatif untuk meningkatkan aktivitas dan hasil belajar teknik dasar passing (chest pass dan bounce pass) bola basket. Selain itu, penerapan model pembelajaran kooperatif tipe TPS ini juga dapat dijadikan referensi dan prinsip fundamental yang bersifat progresif dan konstruksif dalam meneliti cabang olahraga yang lain terutama dalam peningkatan kualitas proses pembelajaran.

\section{Daftar Pustaka}

Dimiyati dan Mudjiono. 2006. Belajar dan Pembelajaran. Jakarta: Rineka Cipta.

Hamalik. 2008. Proses Belajar Mengajar. Jakarta:Bumi Aksara.

Kanca, I Nyoman. 2010. Metodologi Penelitian Keolahragaan. Singaraja : Universitas Pendidikan Ganesha.

Nurhadi. 2004. Pembelajaran Kontekstual dan Penerapannya dalam KBK. Malang: Universitas Negeri Malang.

Nurkancana dan Sunartana. 1990. Evaluasi Hasil Belajar. Surabaya: Usaha Nasional.

Permendikbud no 65. 2013. Tentang Standar Isi Pendidikan Dasar dan Menengah. Jakarta:

Kemendikbud

Sudjana. 2004. Penilaian Hasil Proses Belajar Mengajar. Bandung: Remaja Rosdakarya.

Sugiyanto. 1998. Perkembangan dan Belajar Motorik. Jakarta:Departemen Pendidikan dan Kebudayaan.

Trianto. 2007. Model-Model Pembelajaran Inovatif. Jakarta: Prestasi Pustaka Publisher. 